\title{
Sox4 stimulates B-catenin activity through induction of CK2
}

\author{
AE-KYUNG LEE ${ }^{1}$, SANG-GUN AHN ${ }^{2}$, JUNG-HOON YOON ${ }^{2}$ and SOO-A KIM ${ }^{1}$ \\ ${ }^{1}$ Department of Biochemistry, Dongguk University College of Oriental Medicine, Gyeongju 780-714; \\ ${ }^{2}$ Department of Oral Pathology, Chosun University College of Dentistry, Gwangju 501-759, Republic of Korea
}

Received August 23, 2010; Accepted November 2, 2010

DOI: $10.3892 /$ or.2010.1091

\begin{abstract}
B-catenin is a key component of the Wnt signaling pathway and the abnormal accumulation of $\beta$-catenin is characteristic of various types of cancer. Here we demonstrate that overexpression of Sox 4 enhances $B$-catenin/TCF activity by increasing the stability of $\beta$-catenin. Sox 4 increased the protein level of $B$-catenin and its target gene cyclin D1 in a dose-dependent manner. An siRNA experiment for Sox 4 also demonstrated that Sox 4 increases the protein levels of $\beta$-catenin and thus activates the Wnt signaling pathway. We found that induction of $\beta$-catenin/TCF activity by Sox 4 is caused by stabilization of the $\beta$-catenin protein, but not by induction of $\beta$-catenin transcription. We further demonstrate that the increased level of $\beta$-catenin is caused by induction of CK2. In light of recent evidence that Sox 4 expression is activated in the colon and in other tumors with $\beta$-catenin dysregulation, our findings suggest that Sox 4 acts as an agonist of Wnt signaling in cancer cells.
\end{abstract}

\section{Introduction}

B-catenin plays a dual role in cells as a major structural component of cell-cell adherens junctions and as a pivotal signaling molecule in the Wnt signaling pathway. Wnt signaling plays a central role in regulation of cellular proliferation, differentiation, and morphogenesis, and is dependent on tightly regulated control of $\beta$-catenin stability (1-3). When active and present in a multi-protein complex containing adenomatous polyposis coli (APC) and Axin1 and/or Axin2 (also known as Axil or conductin), glycogen synthase 3ß (GSK3ß) can phosphorylate specific serine and/or threonine residues near the $B$-catenin $\mathrm{N}$-terminus (3-5). The phosphorylated form of $B$-catenin is ubiquitinated and degradated by the proteasome $(2,3,6)$. Upon Wnt signaling, $\beta$-catenin is stabilized and translocated to the nucleus, where it can bind

Correspondence to: Dr Soo-A Kim, Department of Biochemistry, Dongguk University College of Oriental Medicine, 707 Seokjangdong, Gyeongju-si, Gyeongsangbuk-do 780-714, Republic of Korea E-mail: ksooa@dongguk.ac.kr

Key words: Sox4, ß-catenin, Wnt, casein kinase 2, colorectal cancer to members of the $\mathrm{T}$ cell factor (TCF)/lymphoid enhancer family (LEF) transcription factor family $(7,8)$. In the nucleus, TCFs mediate sequence-specific DNA binding, and $\beta$ catenin, via its interaction with TCFs, activates transcription of target genes $(1,9,10)$.

Defects that alter $\beta$-catenin regulation have been reported in various human cancers. Mutations in $\beta$-catenin gene (CTNNB1) sequences encoding crucial GSK3ß phosphorylation sites in the $\mathrm{B}$-catenin $\mathrm{N}$-terminal domain have been found in many different cancers (10). In upwards of $\sim 80 \%$ of colorectal cancers, inactivation of the $A P C$ tumor suppressor gene is the predominant mechanism leading to $ß$-catenin deregulation $(1,11)$. In other cancers, mutations in the genes encoding one of the two Axin proteins have been reported (12-15). A prime consequence of mutational defects in B-catenin regulation is constitutive activation of downstream B-catenin-TCF-regulated target genes, including genes with major effects on cell growth regulation and tumorigenesis, such as $c-M Y C$ and Cyclin DI (16-18).

SRY-related HMG box (Sox) genes encode a family of transcription factors that are crucial for embryonic development. At least 30 members of the SOX family have been identified so far and are expressed in many different cell types and tissues at multiple stages during development (19-21). However, the precise function(s) of many SOX proteins is still unknown.

Sox 4 was first identified as a transcription factor required for B- and T-lymphocyte differentiation (22). Sox4 appears to be critical for normal development and maturation of endocardial cushions and for normal B-cell maturation; however, its function(s) in these processes is not yet clear. Recent studies have demonstrated high expression of Sox 4 in several tumors including breast cancer, colon cancer, salivary adenoid cystic carcinoma, and medulloblastomas, suggesting that Sox 4 may play a role in tumorigenesis (23-29).

Of particular interest, several studies have suggested possible cross-talk between Sox and $\beta$-catenin by showing that several of the Sox proteins, such as Sox3, Sox7, Sox9, and Sox 17 modulate Wnt signaling (30-34). Sinner et al recently showed that Sox 17 represses Wnt signaling by promoting degradation of $\beta$-catenin and TCF via a GSK3ßindependent mechanism. They also reported that unlike Sox17, Sox4 enhances the Wnt signaling pathway (35). However, the precise action mechanism of Sox 4 on B-catenin is unclear. In this study, we examined the effect of Sox 4 on $\beta$-catenin and reported evidence showing that Sox 4 stabilizes B-catenin by inducing the level of casein kinase 2 (CK2). 


\section{Materials and methods}

Cell culture and transfection. HEK 293 and SW480 cells were maintained at $37^{\circ} \mathrm{C}$ with $5 \% \mathrm{CO}_{2}$ in Dulbecco's modified Eagle's medium supplemented with $100 \mathrm{U} / \mathrm{ml}$ penicillin, $100 \mu \mathrm{g} / \mathrm{ml}$ streptomycin, and $10 \%$ fetal bovine serum. HEK 293 cells were transiently transfected with various expression vectors using FuGENE ${ }^{\circledR}$ HD (Roche Molecular Biochemicals, Indianapolis, IN) according to the manufacturer's instructions. An electroporator $\left(\mathrm{Neon}^{\mathrm{TM}}\right.$ Transfection System, Invitrogen, Carlsbad, CA) was used for transfection of SW480 cells.

Plasmids. The complete open reading frame of Sox4 (1425 nucleotides) corresponding to GenBank accession number NM_003107 was amplified by PCR using human skeletal muscle cDNA as a template (Clontech, Mountain View, CA). Mammalian expression vectors for N-terminally FLAG-tagged Sox 4 proteins were created by insertion of cDNA fragments into the 5' HindIII and 3' EcoRI sites of pCDNA3.1-FLAG. All constructs were confirmed by DNA sequencing. The reporter constructs pTOPFLASH, which contains three copies of an optimal TCF binding motif (CCTTTGATC), and pFOPFLASH, which contains three copies of a mutant motif (CCTTTGGCC), have been described (36). Plasmid pCH110 (GE Healthcare, Piscataway, NJ) contains a functional $\mathrm{LacZ}$ gene cloned downstream of a cytomegalovirus early-region promoter-enhancer element.

Immunoprecipitation and immunoblotting. For immunoprecipitation, SW480 cells were transiently transfected using an electroporator (Neon Transfection System, Invitrogen), according to the manufacturer's instructions. After $48 \mathrm{~h}$, cells were washed twice with PBS and lysed in RIPA buffer (PBS supplemented with $1 \%$ Nonidet P-40, $0.5 \%$ sodium deoxycholate, $1 \mathrm{mM}$ PMSF, $1 \mu \mathrm{g} / \mathrm{ml}$ aprotinin, and $1 \mathrm{mM}$ sodium orthovanadate). Cell lysates were harvested and incubated at $4^{\circ} \mathrm{C}$ for $30 \mathrm{~min}$ and cleared by centrifugation at $10,000 \mathrm{x} \mathrm{g}$ for $10 \mathrm{~min}$. Supernatant was incubated with agarose-conjugated anti-FLAG antibody (Sigma-Aldrich, St. Louis, MO) for $3 \mathrm{~h}$. Immunoprecipitates were washed 4 times with RIPA buffer containing $0.05 \%$ SDS and boiled in SDS-PAGE sample buffer. For immunoblotting, proteins were resolved by SDSPAGE and immunoblotted using antibodies against FLAG, actin (Sigma-Aldrich), ß-catenin (Millipore, Bedford, MA), GSK3ß (BD Transduction Laboratories, Rockville, MD), phospho-GSK3ß (Cell Signaling Technology, Danvers, MA), CK2, cyclin D1, cyclin D3, and c-myc (Santa Cruz Biotechnology, Santa Cruz, CA).

Luciferase reporter gene assay. To assess the effects of Sox4 on endogenous $B$-catenin-induced TCF activity, SW480 cells $\left(2 \times 10^{7}\right.$ cells $)$ were co-transfected with pTOPFLASH or pFOPFLASH, pCDNA3.1-FLAG-Sox4, and pCH110 using the Neon Transfection System (Invitrogen) and seeded on 12-well plate. The total mass of transfected DNA in each well was kept constant by addition of empty vector DNA, when necessary. After 48 h, cells were washed twice with PBS and lysed with Reporter Lysis Buffer (Promega, Madison, WI). Luciferase activity was measured using the Luciferase
Activity Assay kit, as described by the manufacturer (Promega). All experiments were performed in triplicate, and the mean \pm SD values were determined. $\beta$-galactosidase activities were determined in order to normalize the luciferase activities.

Semi-quantitative RT-PCR. Total RNA was isolated with TRIzol ${ }^{\circledR}$ reagent (Invitrogen). RT-PCR was conducted using the ONE-STEP RT-PCR PreMix kit (iNtRON Biotechnology, Korea) according to the manufacturer's instructions. Primers used in the RT-PCR reaction are: $\beta$-catenin forward primer (5'-CACAGCTCCTCTGACAGAGTTACTTCACTC-3') and reverse primer (5'-CTCAGCTTGGTTAGTGTGTCAG GCA-3'); cyclin D1 forward primer (5'-CGTCTCGGGA GAGGATTAGGTTCC-3') and reverse primer (5'-CCA AGTAGCTGTGGGTTGAACCTG-3'); GAPDH forward primer (5'-CCAAGGTCATCCATGACAACTTTG-3'), and reverse primer (5'-GTCATACCAGGAAATGAGCTTG ACA-3'). RT-PCR was performed under the following cycle conditions: 1 cycle of $30 \mathrm{~min}$ at $45^{\circ} \mathrm{C}, 1$ cycle of $5 \mathrm{~min}$ at $94^{\circ} \mathrm{C}$, and 22 cycles of $30 \mathrm{sec}$ at $94^{\circ} \mathrm{C}, 30 \mathrm{sec}$ at $55^{\circ} \mathrm{C}\left(63^{\circ} \mathrm{C}\right.$ for cyclin D1), and $50 \mathrm{sec}$ at $72^{\circ} \mathrm{C}$, with a final extension at $72^{\circ} \mathrm{C}$ for $5 \mathrm{~min}$. PCR products were then electrophoresed on $1.5 \%$ agarose gels and visualized by ethidium bromide staining.

siRNA experiment. The Sox 4 siRNA construct was obtained as Silencer ${ }^{\circledR}$ Pre-designed siRNA (Applied Biosystems, Foster City, CA). HEK 293 cells were transfected with $50 \mathrm{nM}$ of siRNA using X-tremeGENE siRNA Transfection Reagent (Roche Molecular Biochemicals), according to the manufacturer's instructions. After $48 \mathrm{~h}$, cells were harvested and cell lysates were separated by SDS-PAGE. The expression level of Sox 4 was analyzed by immunoblotting, as described above.

\section{Results}

Sox 4 increases the level of endogenous $\beta$-catenin. Among Sox family members, Sox 4 is of great interest in respect to cancers because recent studies have provided evidence that Sox 4 is involved in tumorigenesis of various human cancers (23-29). To examine the reciprocal relationship between Sox 4 and B-catenin, HEK 293 cells were transfected with expression vectors for FLAG-tagged Sox4. Thirty hours after transfection, cells were lysed and Western blot analysis was performed using anti- $\beta$-catenin and anti-FLAG antibody. The result shown in Fig. 1A clearly demonstrate that the levels of endogenous $\beta$-catenin were increased with increasing concentrations of Sox4. In accordance with this result, when the cells were transfected with Sox 4 siRNA, the level of Bcatenin was decreased (Fig. 1B). Furthermore, Sox 4 knockdown resulted in a significant reduction in the levels of c-myc and Cyclin D, typical targets of the Wnt signaling pathway, suggesting that Sox4 up-regulates the level of endogenous $\beta$-catenin.

Sox4 activates the Wnt signaling pathway by stabilizing the $\beta$-catenin protein. To further demonstrate whether Sox 4 can affect the signaling activity of $\beta$-catenin, $\beta$-catenin/TCF transcriptional activity was measured using the pTOPFLASH 
A

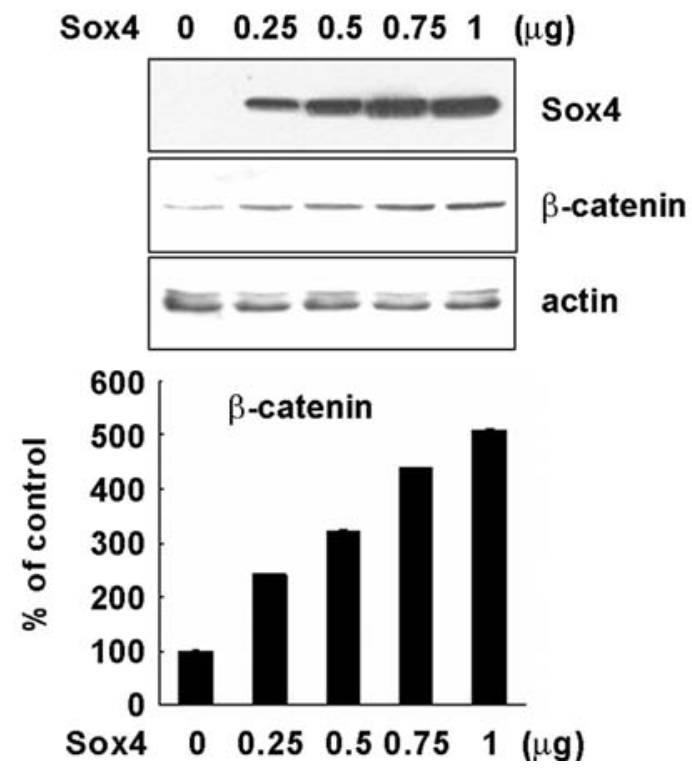

B

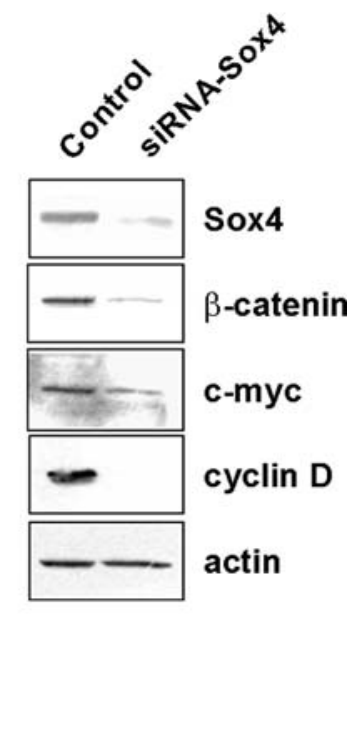

Figure 1. Sox4 up-regulates the levels of endogenous B-catenin. (A) HEK 293 cells were transfected with increasing amounts of FLAG-tagged Sox 4 expression vectors. After $30 \mathrm{~h}$, the levels of Sox 4 and $\beta$-catenin were determined by Western blot analysis using anti-FLAG and anti- $\beta$-catenin antibodies. (B) HEK 293 cells were transfected with Sox 4 siRNA constructs. After 48 h, the protein levels of Sox 4 , B-catenin, c-myc, Cyclin D, and actin were detected by Western blot analysis.

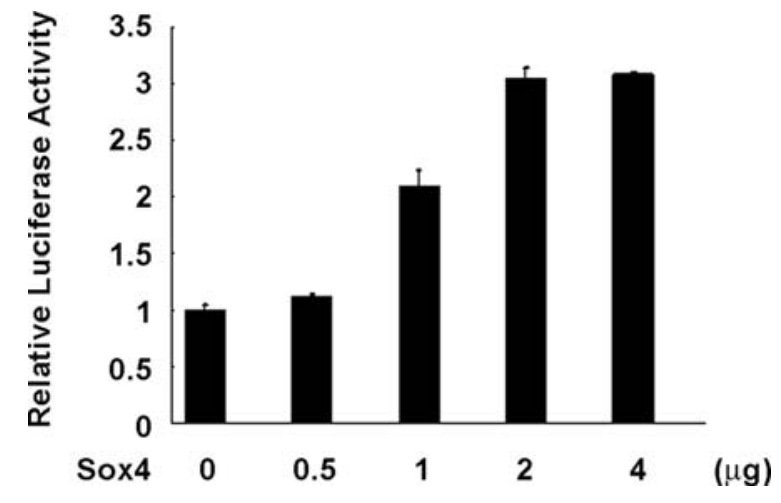

Figure 2. Sox4 induces B-catenin/TCF stimulated transcription. SW480 cells were co-transfected with the pTOPFLASH or pFOPFLASH reporter vector and expression vectors encoding Sox 4 , as indicated. pTOPFLASH contains three TCF binding sites upstream of a luciferase reporter and the pFOPFLASH plasmid has mutated TCF binding motifs. After $48 \mathrm{~h}$, cell extracts were subjected to the luciferase assay. Luciferase activities were normalized for transfection efficiency by co-transfection with a ß-galactosidase-expressing vector, pCH110. Data represent mean values from triplicate experiments.

luciferase reporter vector. pTOPFLASH contains three TCF consensus binding sites and is strongly activated by positive components of the Wnt signaling pathway (36). SW480 human colon adenocarcinoma cells were used for the reporter gene assay. As shown in Fig. 2, transfection of SW480 cells with Sox 4 mammalian expression vector increased transactivation of the pTOPFLASH vector in a dose-dependent manner, suggesting that Sox 4 activates the Wnt signaling pathway.

Endogenous protein levels can be regulated by RNA level and/or protein level. To understand the regulatory mechanism of $\beta$-catenin by Sox 4, SW480 cells were transfected with the Sox 4 expression vector for $48 \mathrm{~h}$ and the protein and RNA levels of B-catenin were examined. As expected, when cells were transfected with the Sox 4 expression vector, protein levels of $\beta$-catenin were increased depending on the Sox 4 concentration, suggesting that Sox 4 increases the endogenous protein level of 3 -catenin (Fig. 3A). Next, in order to verify the effect of Sox 4 on $\beta$-catenin gene expression, we examined the mRNA level of $\beta$-catenin by semi-quantitative RT-PCR. Unlike protein level, mRNA level of ß-catenin was not affected by Sox 4 expression, suggesting that Sox 4 did not affect the transcription level of $\beta$-catenin (Fig. 3B). Both mRNA level and protein level of Cyclin D were increased depending on the Sox 4 concentration, demonstrating that Wnt signaling is activated by Sox 4 . These results suggest that the increased level of $\beta$-catenin by Sox 4 is caused by increased protein stability, but not by transcriptional activity.

Sox4 stabilizes $\beta$-catenin by inducing the level of $C K 2$. Targeting of $\beta$-catenin to the proteasome is achieved through its phosphorylation by GSK3ß in a multiprotein complex. According to our data, Sox 4 up-regulated the protein level of B-catenin, but did not affect the mRNA level, suggesting that Sox 4 may affect phosphorylation of $\beta$-catenin by GSK3ß and subsequent ubiquitination by $\beta-\operatorname{TrCP}$. To verify involvement of GSK3ß on Sox4-mediated induction of B-catenin, cells were treated with $\mathrm{LiCl}$, an inhibitor of GSK3ß activity. As shown in Fig. 4A, $\mathrm{LiCl}$ accumulated the endogenous B-catenin. Similar to results shown by cells treated with $\mathrm{LiCl}$ alone, overexpression of Sox 4 also increased the level of B-catenin (Fig. 4A). This result suggests the possibility that Sox 4 may increase the level of $\beta$-catenin by inhibition of GSK3ß activity. Therefore, we next examined whether Sox 4 affects GSK3ß 
A

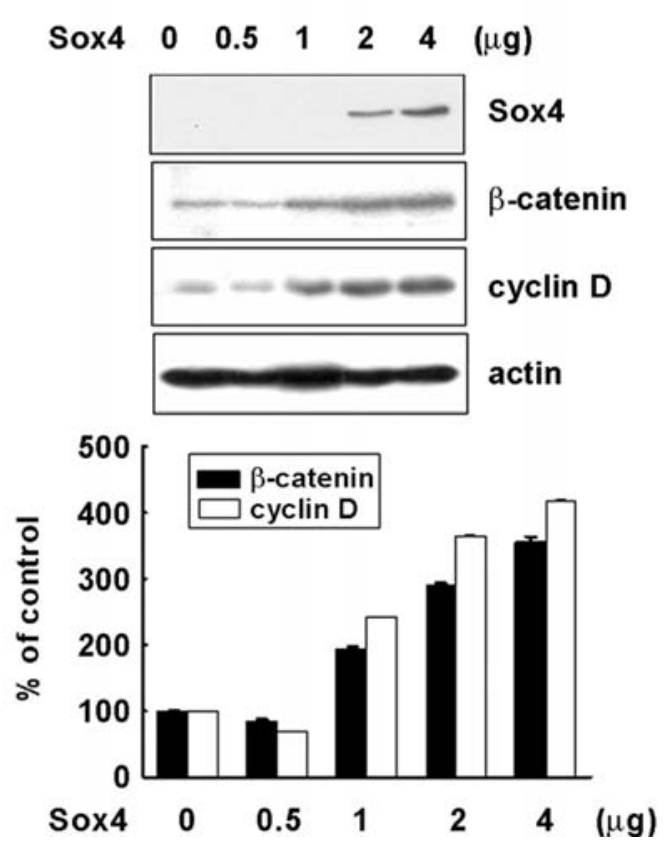

B
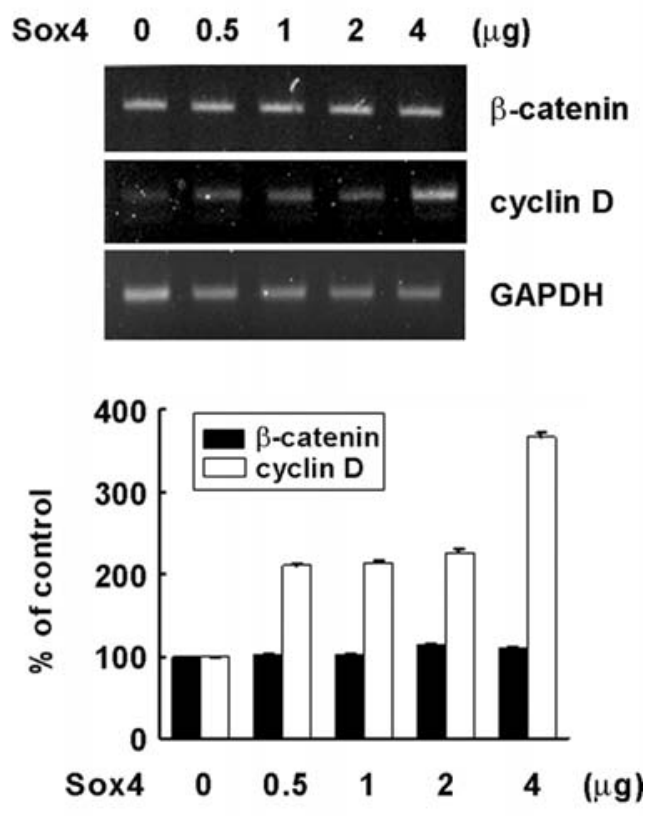

Figure 3. Sox4 up-regulates the protein level but not the mRNA level of B-catenin. SW480 cells were transfected with increasing amounts of FLAG-tagged Sox 4 expression vectors. (A) After $48 \mathrm{~h}$, the protein levels of Sox4, B-catenin, Cyclin D, and actin were detected by Western blot analysis. (B) After $48 \mathrm{~h}$, total RAN was isolated and the expression levels of B-catenin, Cyclin D, and GAPDH were analyzed by semi-quantitative RT-PCR.

A

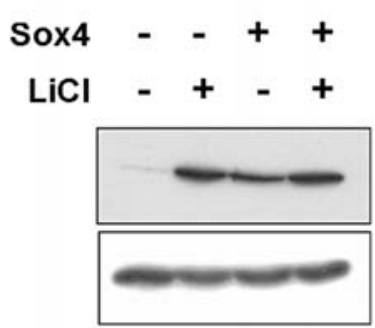

B

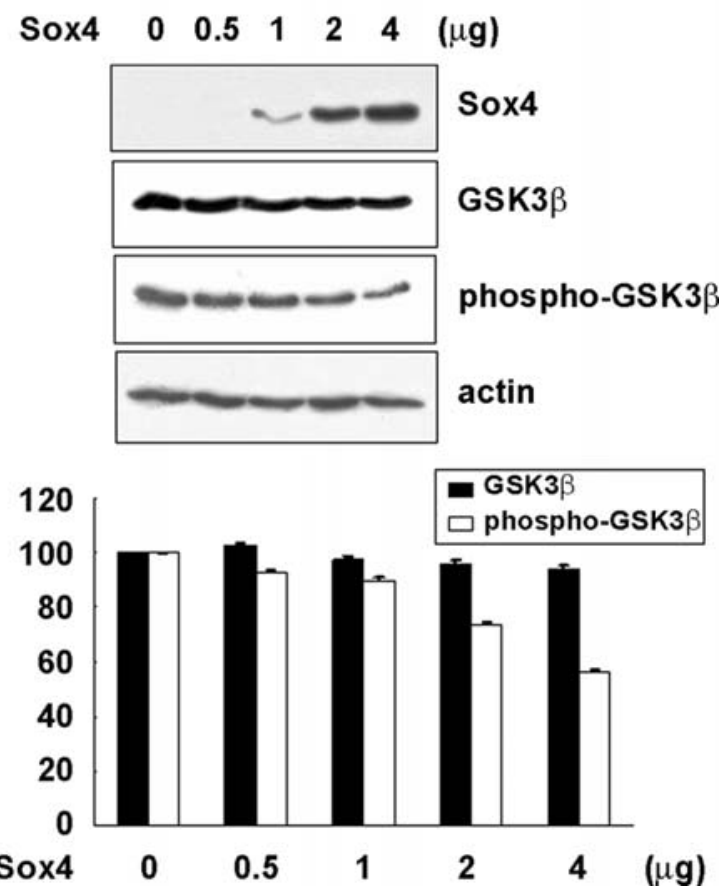

Figure 4. Sox4 slightly decreased the level of phosphorylated GSK3ß. (A) SW480 cells were transfected with the Sox4 expression vector. After 44 h, cells were treated with $\mathrm{LiCl}(30 \mathrm{mM})$ and incubated further $4 \mathrm{~h}$. Cells were harvested and the level of $\beta$-catenin was determined by Western blot analysis. (B) SW480 cells were transfected with increasing amounts of Sox 4 expression vectors. After 48 h, the levels of Sox4, total GSK3B, phospho-GSK3ß, and actin were detected by Western blot analysis.

activity. SW480 cells were transfected with expression vectors for Sox 4 and the levels of total and phosphorylated GSK3ß were examined. Unexpectedly, the level of total GSK3ß was not affected by Sox 4 . Moreover, phosphorylated
GSK3ß, an inactivated form of GSK3ß, was slightly decreased depending on the Sox 4 concentration.

Since Sox 4 did not inactivate GSK3ß, we next examined whether Sox 4 can affect the activity of CK2, another major 
A

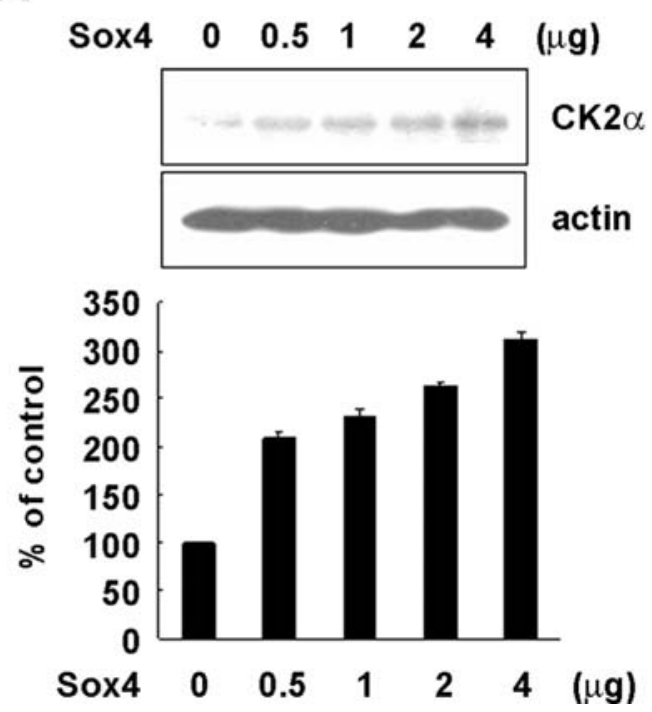

B

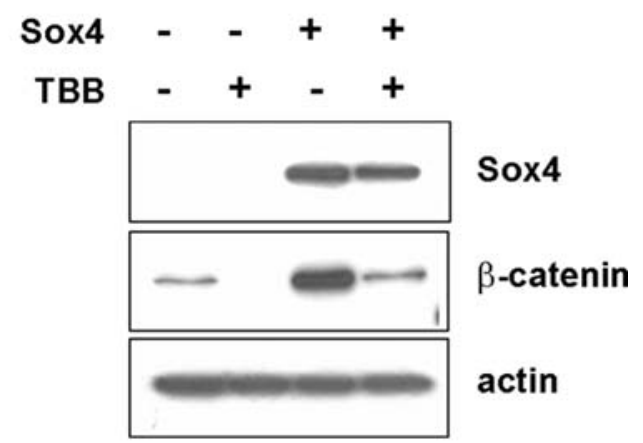

Figure 5. Sox 4 increased the level of CK2. (A) SW480 cells were transfected with the Sox 4 expression vector. After 48 h, cells were harvested and the level of CK $2 \alpha$ was determined by Western blot analysis. (B) SW480 cells were transfected with the Sox 4 expression vector. After 24 h, cells were treated with TBB $(100 \mu \mathrm{M})$ and incubated for further $24 \mathrm{~h}$. Cells were harvested and the level of Sox 4 and ß-catenin was detected by Western blot analysis.

kinase involved in regulation of $\beta$-catenin stability. Previous studies have reported that $\mathrm{CK} 2$ phosphorylates $\beta$-catenin and thereby prevents degradation mediated by the proteasome $(37,38)$. Of particular interest, the level of endogenous CK2 was increased depending on the Sox4 concentration (Fig. 5A). When cells were treated with 4,5,6,7-tetrabromobenzotriazole (TBB), a specific inhibitor of CK2, the level of endogenous B-catenin was decreased (Fig. 5B). However, Sox4 compromise the effect of TBB on $B$-catenin, suggesting that Sox 4 increased the level of endogenous $B$-catenin by increasing protein stability in a CK2-dependent manner.

\section{Discussion}

Increasing evidence has shown that Sox4 is up-regulated in several tumors, such as colon cancer, breast cancer, and salivary gland cancer (23-29). Although the precise molecular mechanism of Sox 4 involvement in tumorigenesis is unclear, several members of the Sox family, including Sox3, Sox7, Sox9, and Sox 17 have been shown to inhibit $\beta$-catenin activity (30-34).

In this study, we demonstrated that Sox 4 up-regulates the endogenous level of B-catenin in both HEK293 and SW480 cells. RNAi experiments have also shown that depletion of Sox4 induced a decreased level of endogenous B-catenin and subsequent decrease of Wnt signaling target proteins, such as c-myc and Cyclin D. Endogenous protein levels can be regulated by RNA level and/or protein level. By showing that Sox 4 did not affect the transcription level of $\beta$-catenin, we first demonstrated that Sox 4 up-regulates endogenous $\beta$-catenin by increasing protein stability.

In the absence of the Wnt signal, $\beta$-catenin is phosphorylated by GSK3ß in its N-terminal domain, resulting in ubiquitination of $\beta$-catenin and its degradation by proteasome. Binding of Wnt to the receptor leads to inhibition of GSK3ß activity through mechanisms that have not been fully clarified. In this study, we demonstrated that Sox 4 up-regulates the amount of endogenous $\beta$-catenin by increasing protein stability. These results suggest the possibility that Sox 4 may up-regulate $\beta$-catenin by regulation of GSK3ß activity. However, our results showed that the level of phosphorylated GSK3ß was slightly decreased while total GSK3ß level was not affected upon Sox 4 overexpression. GSK3ß is a serine-threonine kinase and its active form is non-phosphorylated. Therefore, we ruled out GSK3ß as a factor that controls $\beta$-catenin stability by Sox 4 .

CK2 and GSK3ß are two important kinases which act oppositely on $\beta$-catenin stability. CK2 is a constitutively active serine-threonine kinase and is known to be regulated by the expression level. CK2 is up-regulated in most cancers and has been implicated in cellular transformation and development of tumorigenesis (38-40). Phosphorylation of the armadillo repeat region of $\beta$-catenin by CK2 has been reported to stabilize $\beta$-catenin and to protect it from proteasome degradation. Furthermore, overexpression of CK2 in transgenic mouse models has been reported to result in an increased $B$-catenin level, leading to development of mammary tumors (40). Here we first showed that CK2 is upregulated depending on the Sox 4 concentration. This finding confirms that Sox 4 stimulates the Wnt signaling pathway by inhibiting degradation of the $B$-catenin protein via a CK2dependent mechanism.

CK2 acts as a multisite regulator in the Wnt signaling pathway by phosphorylation and stabilization of both dishevelled and $B$-catenin. Dishevelled is a protein that acts directly downstream of the frizzled receptor. Phosphorylation of dishevelled by CK2 is believed to prevent GSK3ß from phosphorylation of $B$-catenin. In our results, Sox 4 slightly activated GSK3ß, while the level of $\beta$-catenin was increased. This can be explained by the role of CK2, which phosphorylates the dishevelled.

In summary, we showed that Sox 4 enhances $\beta$-catenin/ TCF activity by increasing the stability of $ß$-catenin. We first demonstrated that an induced level of endogenous $B$-catenin 
by Sox 4 is caused by increased protein stability, which is caused by induction of CK2. The exact molecular mechanism responsible for up-regulation of CK2 by Sox 4 remains to be elucidated. However, our data provide a novel mechanism by which Sox 4 acts as an oncogene by increasing endogenous B-catenin in a CK2-dependent manner. These findings represent a new molecular target for cancer therapy that targets the Wnt signaling pathway. Selective Sox4 inhibition or down-regulation in tumors may provide an opportunity for development of novel cancer drugs.

\section{Acknowledgements}

This study was supported by the Korea Research Foundation Grant funded by the Korean Government (MOEHRD) (KRF2007-531-E00009). S.G. Ahn was supported by the National Research Foundation of Korea (NRF) funded by the Ministry of Education, Science and Technology (no. R13-2008-01000000-0).

\section{References}

1. Bienz M and Clevers $\mathrm{H}$ : Linking colorectal cancer to Wnt signaling. Cell 103: 311-320, 2000.

2. Polakis P: More than one way to skin a catenin. Cell 105: 563-566, 2001.

3. Behrens J, Jerchow BA, Wurtele M, Grimm J, Asbrand C, Wirtz R, Kuhl M, Wedlich D and Birchmeier W: Functional interaction of an axin homolog, conductin, with beta-catenin, APC, and GSK3beta. Science 280: 596-599, 1998.

4. Yamamoto H, Kishida S, Uochi T, Ikeda S, Koyama S, Asashima M and Kikuchi A: Axil, a member of the axin family, interacts with both glycogen synthase kinase $3 \beta$ and $\beta$-catenin and inhibits axis formation of Xenopus embryos. Mol Cell Biol 18: 2867-2875, 1998.

5. Hart M, Concordet JP, Lassot I, Albert I, del los Santos R, Durand H, Perret C, Rubinfeld B, Margottin F, Benarous R and Polakis P: The F-box protein B-TrCP associates with phosphorylated $\beta$-catenin and regulates its activity in the cell. Curr Biol 9: 207-210, 1999

6. Kitagawa M, Hatakeyama S, Shirane M, Matsumoto M, Ishida N, Hattori K, Nakamichi I, Kikuchi A, Nakayama K and Nakayama K: An F-box protein, FWD1, mediates ubiquitindependent proteolysis of $\beta$-catenin. EMBO J 18: 2401-2410, 1999.

7. Behrens J, von Kries JP, Kuhl M, Bruhn L, Wedlich D, Grosschedl R and Birchmeier W: Functional interaction of betacatenin with the transcription factor LEF-1. Nature 382: 638-642, 1996.

8. Molenaar M, van de Wetering M, Oosterwegel M, PetersonMaduro J, Godsave S, Korinek V, Roose J, Destree O and Clevers H: XTcf-3 transcription factor mediates beta-catenininduced axis formation in Xenopus embryos. Cell 86: 391-399, 1996.

9. Peifer $\mathrm{M}$ and Polakis $\mathrm{P}$ : Wnt signaling in oncogenesis and embryogenesis - a look outside the nucleus. Science 287 1606-1609, 2000.

10. Polakis P: Wnt signaling and cancer. Genes Dev 14: 1837-1851, 2000

11. Kinzler KW and Vogelstein B: Lessons from hereditary colorectal cancer. Cell 87: 159-170, 1996.

12. Satoh S, Daigo Y, Furukawa Y, Kato T, Miwa N, Nishiwaki T, Kawasoe T, Ishiguro H, Fujita M, Tokino T, Sasaki Y, Imaoka S, Murata M, Shimano T, Yamaoka Y and Nakamura Y: AXIN 1 mutations in hepatocellular carcinomas, and growth suppression in cancer cells by virus-mediated transfer of AXIN1. Nat Genet 24: $245-250,2000$

13. Liu W, Dong X, Mai M, Seelan RS, Taniguchi K, Krishnadath KK, Halling KC, Cunningham JM, Boardman LA, Qian C, Christensen E, Schmidt SS, Roche PC, Smith DI and Thibodeau SN: Mutations in AXIN2 cause colorectal cancer with defective mismatch repair by activating beta-catenin/TCF signaling. Nat Genet 26: 146-147, 2000.
14. Dahmen RP, Koch A, Denkhaus D, Tonn JC, Sorensen N, Berthold F, Behrens J, Birchmeier W, Wiestler OD and Pietsch T: Deletions of AXIN1, a component of the WNT/wingless pathway, in sporadic medulloblastomas. Cancer Res 61: 7039-7043, 2001.

15. Wu R, Zhai Y, Fearon ER and Cho KR: Diverse mechanisms of B-catenin deregulation in ovarian endometrioid adenocarcinomas. Cancer Res 61: 8247-8255, 2001.

16. He TC, Sparks AB, Rago C, Hermeking H, Zawel L, Da Costa LT, Morin PJ, Vogelstein B and Kinzler KW: Identification of c-MYC as a target of the APC pathway. Science 281: 1509-1512, 1998.

17. Tetsu $\mathrm{O}$ and McCormick F: Beta-catenin regulates expression of cyclin D1 in colon carcinoma cells. Nature 398: 422-426, 1999.

18. Shtutman M, Zhurinsky J, Simcha I, Albanese C, D'Amico M, Pestell R and Ben-Ze'ev A: The cyclin D1 gene is a target of the B-catenin/LEF-1 pathway. Proc Natl Acad Sci USA 96: 5522-5527, 1999.

19. Wegner M: From head to toes: the multiple facets of Sox proteins. Nucleic Acids Res 27: 1409-1420, 1999.

20. Soullier S, Jay P, Poulat F, Vanacker JM, Berta P and Laudet V: Diversification pattern of the HMG and SOX family members during evolution. J Mol Evol 48: 517-527, 1999.

21. Bowles J, Schepers G and Koopman P: Phylogeny of the SOX family of developmental transcription factors based on sequence and structural indicators. Dev Biol 227: 239-255, 2000.

22. Schilham MW and Clevers H: HMG box containing transcription factors in lymphocyte differentiation. Semin Immunol 10: $127-132,1998$

23. Frierson HF Jr, El-Naggar AK, Welsh JB, Sapinoso LM, Su AI, Cheng J, Saku T, Moskaluk CA and Hampton GM: Large scale molecular analysis identifies genes with altered expression in salivary adenoid cystic carcinoma. Am J Pathol 161: 1315-1323, 2002.

24. Lee CJ, Appleby VJ, Orme AT, Chan WI and Scotting PJ: Differential expression of SOX4 and SOX11 in medulloblastoma. J Neurooncol 57: 201-214, 2002.

25. Andersen CL, Christensen LL, Thorsen K, Schepeler T, Sorensen FB, Verspaget HW, Simon R, Kruhoffer M, Aaltonen LA, Laurberg S and Orntoft TF: Dysregulation of the transcription factors SOX4, CBFB and SMARCC1 correlates with outcome of colorectal cancer. Br J Cancer 100: 511-523, 2009.

26. Dong C, Wilhelm D and Koopman P: Sox genes and cancer. Cytogenet Genome Res 105: 442-447, 2004.

27. McCracken S, Kim CS, Xu Y, Minden M and Miyamoto NG: An alternative pathway for expression of p56lck from type I promoter transcripts in colon carcinoma. Oncogene 15: 2929-2937, 1997.

28. McGowan EM and Clarke CL: Effect of overexpression of progesterone receptor A on endogenous progestin-sensitive endpoints in breast cancer cells. Mol Endocrinol 13: 1657-1671, 1999.

29. Reichling T, Goss KH, Carson DJ, Holdcraft RW, Ley-Ebert C, Witte D, Aronow BJ and Groden J: Transcriptional profiles of intestinal tumors in Apc (Min) mice are unique from those of embryonic intestine and identify novel gene targets dysregulated in human colorectal tumors. Cancer Res 65: 166-176, 2005.

30. Zorn AM, Barish GD, Williams BO, Lavender P, Klymkowsky MW and Varmus HE: Regulation of Wnt signaling by Sox proteins: XSox $17 \alpha / \beta$ and XSox3 physically interact with B-catenin. Mol Cell 4: 487-498, 1999.

31. Takash W, Canizares J, Bonneaud N, Poulat F, Mattei M-G, Jay P and Berta P: Sox7 transcription factor: sequence, chromosomal localisation, expression, transactivation and interference with Wnt signaling. Nucleic Acids Res 29: 4274-4283, 2001.

32. Zhang C, Basta T, Jensen ED and Klymkowsky MW: The ß-catenin/VegT-regulated early zygotic gene $\mathrm{Xnr} 5$ is a direct target of Sox3 regulation. Development 130: 5609-5624, 2003.

33. Sinner D, Rankin S, Lee M and Zorn AM: Sox17 and B-catenin cooperate to regulate the transcription of endodermal genes. Development 131: 3069-3080, 2004.

34. Blache $\mathrm{P}$, van de Wetering M, Duluc I, Domon C, Berta P, Freund J-N, Clevers H and Jay P: Sox9 is an intestine crypt transcription factor, is regulated by the Wnt pathway, and represses the CDX2 and MUC2 genes. J Cell Biol 166: 37-47, 2004.

35. Sinner D, Kordich JJ, Spence JR, Opoka R, Rankin S, Lin SC, Jonatan D Zorn AM and Wells JM: Sox 17 and Sox4 differentially regulate beta-catenin/T-cell factor activity and proliferation of colon carcinoma cells. Mol Cell Biol 27: 7802-7815, 2007. 
36. Korinek V, Barker N, Morin PJ, van Wichen D, de Weger R, Kinzler KW, Vogelstein B and Clevers H: Constitutive transcriptional activation by a beta-catenin-Tcf complex in APC $^{-/}$colon carcinoma. Science 275: 1784-1787, 1997.

37. Song DH, Dominguez I, Mizuno J, Kaut M, Mohr SC and Seldin DC: CK2 phosphorylation of the armadillo repeat region of beta-catenin potentiates Wnt signaling. J Biol Chem 278: 24018-24025, 2003.

38. Duncan JS and Litchfield DW: Too much of a good thing: The role of protein kinase $\mathrm{CK} 2$ in tumorigenesis and prospects for therapeutic inhibition of CK2. Biochim Biophys Acta 1784: $33-47,2008$.
39. Dominguez I, Sonenshein GE and Seldin DC: CK2 and its role in Wnt and NF-kappaB signaling: linking development and cancer. Cell Mol Life Sci 66: 1850-1857, 2009.

40. Seldin DC, Landesman-Bollag E, Farago M, Currier N, Lou D and Dominguez I: CK2 as a positive regulator of Wnt signaling and tumourigenesis. Mol Cell Biochem 274: 63-67, 2005. 